\title{
Recovery of small-scale infiltration and erosion after wildfires
}

\author{
Sierra S. Larson-Nash ${ }^{1}$, Peter R. Robichaud ${ }^{2 *}$, Fredrick B. Pierson ${ }^{3}$, Corey A. Moffet ${ }^{4}$, C. Jason \\ Williams ${ }^{5}$, Kenneth E. Spaeth ${ }^{6}$, Robert E. Brown ${ }^{2}$, Sarah A. Lewis ${ }^{2}$
}
${ }^{1}$ Meter Group, 2365 Northeast Hopkins Court, Pullman, WA 99163, USA formally with US Department of Agriculture, Forest Service, Rocky Mountain Research Station. E-mail: sierra.larson-nash@metergoup.com
${ }^{2}$ US Department of Agriculture, Forest Service, Rocky Mountain Research Station, 1221 S. Main St., Moscow, ID 83843, USA. E-mails: probichaud@fs.fed.us; bbrown02@fs.fed.us; sarahlewis@fs.fed.us
${ }^{3}$ US Department of Agriculture, Agricultural Research Service, Northwest Watershed Research Center, 800 E. Park Blvd., Boise, ID 83712, USA. E-mail: fred.pierson@ars.usda.gov
${ }^{4}$ US Department of Agriculture, Agricultural Research Service, $200018^{\text {th }}$ Street, Woodward, OK 73801 USA. E-mail: corey.moffet@ars.usda.gov
${ }^{5}$ US Department of Agriculture, Agricultural Research Service, Southwest Watershed Research Center, 2000 E. Allen Road, Tucson, AZ 85719 USA, formally with USDA, Agricultural Research Service, Northwest Watershed Research Center. E-mail: jason.williams@ars.usda.gov
${ }^{6}$ US Department of Agriculture, Natural Resources Conservation Service, Central National Technology Support Center, 501 W. Felix St., FWFC, Building 23, Fort Worth, TX 76115, USA. E-mail: Ken.Spaeth@ftw.usda.gov
* Corresponding author. Tel.: 208883 2349. E-mail: probichaud@fs.fed.us

\begin{abstract}
Wildfires naturally occur worldwide, however the potential disruption to ecosystem services from subsequent post-fire flooding and erosion often necessitates a response from land managers. The impact of high severity wildfire on infiltration and interrill erosion responses was evaluated for five years after the 2003 Hot Creek Fire in Idaho, USA. Relative infiltration from mini-disk tension infiltrometers (MDI) was compared to rainfall simulation measurements on small burned and control plots. Vegetation recovery was slow due to the severity of the fire, with median cover of 6-8\% on burned sites after 5 years. Consequently, interrill sediment yields remained significantly higher on the burned sites (329-1200 $\mathrm{g} \mathrm{m}^{-2}$ ) compared to the unburned sites $\left(3-35 \mathrm{~g} \mathrm{~m}^{-2}\right)$ in year 5. Total infiltration on the burned plots increased during the study period, yet were persistently lower compared to the control plots. Relative infiltration measurements made at the soil surface, and 1- and 3-cm depths were significantly correlated to non-steady state total infiltration values taken in the first 10 minutes of the hour-long rainfall simulations. Significant correlations were found at the $1-\mathrm{cm}(\rho=$ $0.4-0.6)$ and $3-\mathrm{cm}(\rho=0.3-0.6)$ depths (most $p$-values $<0.001)$, and somewhat weaker correlations at the soil surface $(\rho=0.2-0.4)$ ( $p$-values $<0.05$ and up). Soil water repellency is often stronger below the soil surface after severe wildfire, and likely contributes to the reduced infiltration. These results suggest that relative infiltration measurements at shallow depths may be useful to estimate potential infiltration during a short-duration high-intensity storm and could be used as an input for post-fire erosion models.
\end{abstract}

Keywords: Interrill erosion; Mini-disk infiltrometer; Post-fire erosion; Rainfall simulation; Water repellency.

\section{INTRODUCTION}

Wildfires and subsequent post-fire flooding and erosion are natural processes within healthy forest ecosystems worldwide (Agee, 1996; Imeson et al., 1992; Prosser and Williams, 1998; Townsend and Douglas, 2000). However, these processes often threaten life, property and natural resources both inside and outside of the burned area and consequently, a response from land managers is required (Moody et al., 2013; Neary et al., 2005).

Multiple factors contribute to elevated flooding and erosion risk following fire, including loss of water storage in the forest litter and duff, reduction in leaf interception from canopy loss and reduced understory vegetation cover, decreased infiltration and creation or exacerbation of water repellent soil conditions (Shakesby et al., 2000). Many of these factors are closely related to soil burn severity, defined as the effect of fire on ground cover and soil characteristics (e.g., ash depth, organic matter loss, reduced infiltration and altered soil structure) (DeBano et al., 1998; Larsen et al., 2009; Lentile et al., 2006; Parsons et al., 2010; Ryan and Noste, 1985).

Post-fire erosion is often inversely correlated to remaining ground cover that protects the mineral soil (vegetation and forest litter), which commonly decreases with increasing soil burn severity (Benavides-Solorio and MacDonald, 2005; Cerdà, 1996; Johansen et al., 2001; Parsons et al., 2010; Robichaud et al., 2013a). As ground cover is reestablished, infiltration rate and sediment yield tend to return to pre-fire levels (Cerdà, 1996; Pierson et al., 2008). This recovery process generally takes three to five years (Goetz et al., 2006; Robichaud et al., 2013a; Wine and Cadol, 2016), but recovery times of 5 to 14 years have been measured (DeBano et al., 1996; Robichaud et al., 2013b). The return to pre-fire conditions is affected by many characteristics such as the degree of soil burn severity, soil type, fire location within the watershed, ecosystem, topography, post-fire meteorological conditions and longer-term climate (Cerdà and Robichaud, 2009).

High soil burn severity may also cause or exacerbate water repellency in soils (Doerr et al., 2009a) which varies by inherent soil characteristics, soil moisture, and time since fire. Soil water repellency can develop when surface vegetation and litter are burned and the volatilized organic compounds are released into the soil profile where they condense on soil particles (DeBano, 1971; Ice et al., 2004; Shakesby and Doerr, 2006). Fire-induced soil water repellency is often detected 1- to $3-\mathrm{cm}$ below the soil surface (Doerr et al., 2006; Robichaud, 2000) 
and can exhibit high spatial variability (Lewis et al., 2008; Wagenbrenner and Robichaud, 2014). Given that the most apparent hydrological effect of soil water repellency is reduced infiltration, post-fire assessment teams have often used a field test of soil water repellency to estimate the reduction in infiltration.

The availability of the mini-disk tension infiltrometers provides a new opportunity for post-fire assessment teams to make quick field measurements of relative infiltration (relative to the instrument and test time). Both Lewis et al. (2006) and Robichaud et al. (2008) found that water drop penetration time (WDPT) tests and mini-disk infiltrometer measurements (1-min duration, mini-disk infiltrometer) (Decagon Devices, 2016) were closely related and either method would be suitable to predict soil water repellency. However, mini-disk infiltrometer measurements and their relation to small-plot-scale total infiltration (as measured by rainfall simulation) have not been studied.

Soil water repellency also occurs naturally in many different soils and environments (i.e. coarse grained soils in Australia, ash cap soils in Montana, and under vegetation types such as California chaparral and Big Sagebrush) (Doerr et al., 2009b; Hubbert et al., 2006; Huffman et al., 2001; Pierson et al., 2008; Robichaud et al., 2016). Since forest floor cover and naturally occurring, or inherent, water repellent soils often vary spatially on hillslopes, soil water repellency may not always reduce infiltration at the hillslope scale (Barrett and Slaymaker, 1989; Burch et al., 1989; DeBano, 1981; Robichaud et al., 2016). In the immediate post-fire assessment period, land managers need timely data to make informed decisions about watershed mitigation treatments (Robichaud and Ashmun, 2013). We postulate that the mini-disk infiltrometer will provide information about soil water repellency and infiltration characteristics that will help inform managers in their decision making process.

This study applied a suite of vegetation and soil measurements, and small-plot rainfall simulations to: 1) determine the effects of high soil burn severity wildfire and slope steepness on vegetation and ground cover, soil water repellency, infiltration, runoff, and sediment yield from splash-sheet processes called interrill erosion; 2) determine how these variables change with time after fire; and 3) evaluate the correlations between the mini-disk field infiltrometer measurements at several depths and infiltration rates calculated from the rainfall simulations.

\section{METHODS \\ Site characteristics}

Experimental plots were established at the 2003 Hot Creek Fire, which ignited on 19 July and was contained on 7 August in south central Idaho (Figure 1). Of the 10,000 ha burned, more than $60 \%$ of the area was classified as moderate or high soil burn severity and more than half was identified as having water repellent soils (USDA, 2003). These data indicate severe fire conditions and watershed disturbance.
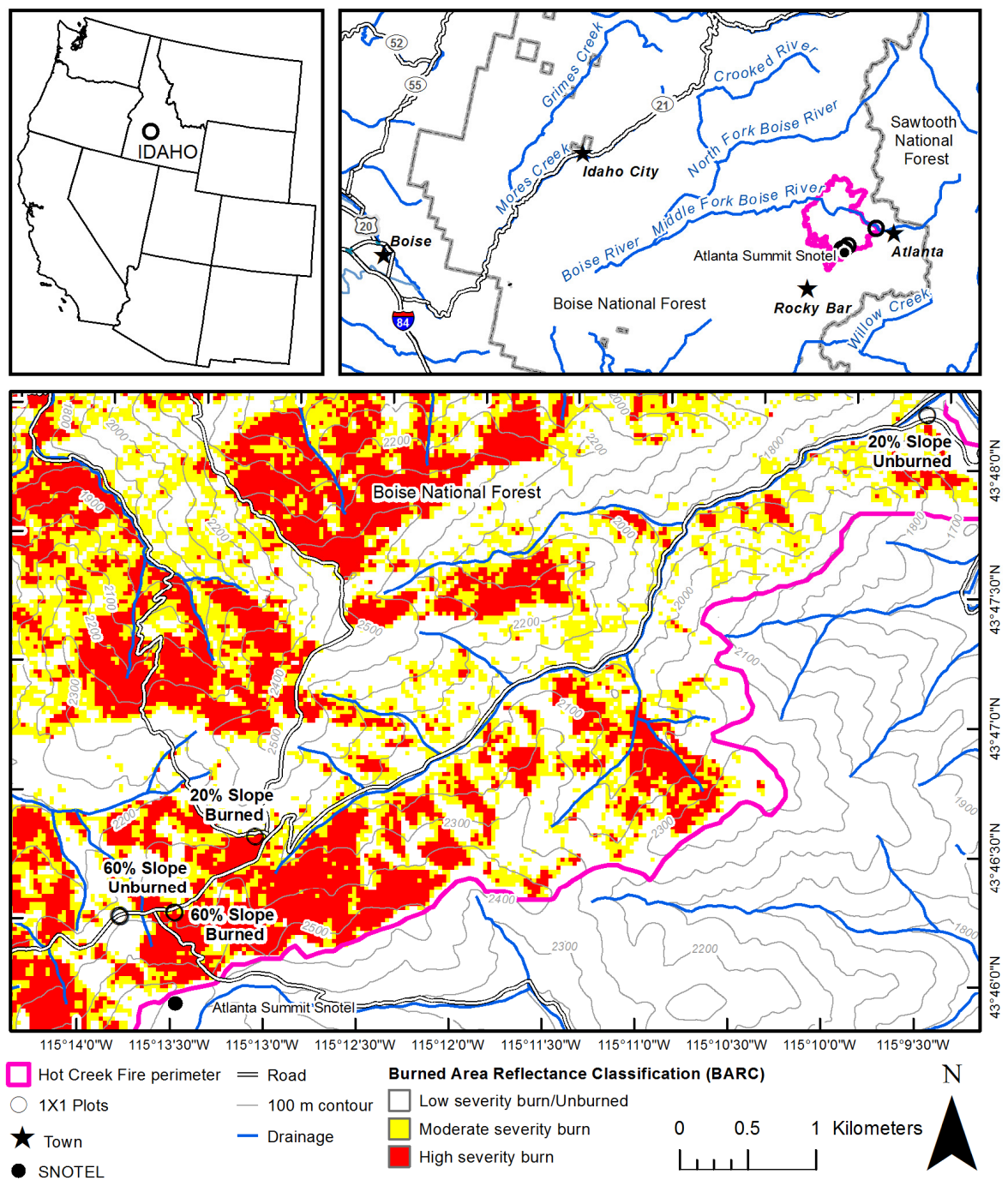

Fig. 1. Site map for Hot Creek Fire study area. 
Recovery of small-scale infiltration and erosion after wildfires

A sandy loam soil (sandy mixed Typic Cryorthent and Typic Xerochrept) with a parent material of Idaho Batholith granite dominated the study area (NRCS, 2010; NRCS, 2011). The prefire vegetation was characterized by Douglas-fir (Pseudotsuga menziesii) and subalpine fir (Labies lasiocarpa) in the overstory with geyers sedge (Carex geyeri) and grouse whortleberry (Vaccinium scoparium) in the understory (Steele et al., 1981). Mean annual precipitation for the study site averaged $1078 \mathrm{~mm}$ ( $\sim 70 \%$ as snow) during the six year study period, as measured at the Atlanta Summit SNOTEL weather station (2310 m elevation) located $2 \mathrm{~km}$ from the study areas. Mean maximum temperature in August during the study period was $28^{\circ} \mathrm{C}$, and mean minimum January temperature was $-17^{\circ} \mathrm{C}$. Yearly precipitation ranged from 831 to $1427 \mathrm{~mm}$ (NWCC, 2010) (Table 1). The rainfall simulation sites were located within $1 \mathrm{~km}$ of each other with elevations ranging between 2000 and $2330 \mathrm{~m}$, except for the $20 \%$ slope-unburned site which was $6 \mathrm{~km}$ from the other sites at an elevation of $1700 \mathrm{~m}$.

Ten rainfall simulation plots $\left(0.5 \mathrm{~m}^{2}\right)$ were established at each of four sites ( 40 plots total) that differed by slope $(20 \%$ and $60 \%$ ) and surface condition (burned at high severity and unburned control). Measurements of vegetation, ground cover, soil properties, and runoff and sediment yield occurred on each plot within 30 days after the fire (fire year, 2003) prior to any natural rainfall events, and was repeated in late summer of postfire years one (2004), two (2005) and five (2008) (Table 2). Four plots were excluded in the rainfall simulations in 2008 because of damage to the plot frames: two each on the $20 \%$ burned and $60 \%$ unburned sites.

Standing dead vegetation, tree stumps, rocks, litter, and live plants by species in each plot were ocularly estimated (Elzinga et al., 1998) two weeks prior to rainfall simulations each year. Calibration and accuracy checks of the ocular ground cover estimates were conducted as described in Pierson et al. (2008). Total ground cover was the summed percent ground cover for each component, and the bare mineral soil was determined by subtracting total ground cover from $100 \%$ (Pierson et al., 2008).

Soil gravimetric water content (GWC) was measured in surface $(0-2 \mathrm{~cm})$ soil samples taken adjacent to each plot immediately prior to the rainfall simulation. Soil samples were oven dried at $100^{\circ} \mathrm{C}$ to determine the percent GWC, which is referred to as soil moisture hereafter.

Water repellency and relative infiltration rate were collected prior to rainfall simulation in a location adjacent to each study plot where the soil surface was fairly uniform and undisturbed by trees, animal burrows, etc. Measurement depths were adjusted by year based on findings by Robichaud et al. (2008) and others (e.g., Doerr et al., 2006). These studies have shown that soil water repellency after burning often occurs in the first few centimeters of the soil profile where hydrophobic compounds condense due to cooler temperatures (DeBano, 1981; Doerr et al., 2006). In the year of the fire, measurements were made at the soil surface only, and measurements in the first and second post-fire years were made at the surface and at each centimeter for depths $1-5 \mathrm{~cm}$. In post-fire year five, measurements were made at the surface and at depths $1-5 \mathrm{~cm}$ on the burned plots, but only at 1- and 3-cm depths on the unburned plots. To compare coincident measurements between years, we analyzed available data from the surface, 1 - and 3-cm depths.

Soil water repellency was measured prior to rainfall simulation using the water drop penetration time (WDPT) test as described in DeBano (1981) and Wilcox et al. (1988). Duff, ash, litter and debris were removed from the soil surface where eight drops of water were placed 5-10 $\mathrm{mm}$ apart with a 2-mm diameter nozzle bulb dropper. The time for each drop to pene-
Table 1. Post-fire precipitation at the Atlanta Summit SNOTEL.

\begin{tabular}{lllll}
\hline & $\begin{array}{l}\text { Post- } \\
\text { fire } \\
\text { Year }\end{array}$ & $\begin{array}{l}\text { Rainfall } \\
\text { simulation } \\
\text { date }\end{array}$ & $\begin{array}{l}\text { Annual } \\
\text { precipitation } \\
(\mathrm{mm})\end{array}$ & $\begin{array}{l}\text { Deviation from } \\
\text { mean annual } \\
\text { precipitation }(\mathrm{mm})\end{array}$ \\
\hline 2003 & 0 & 27 Aug 2003 & 1085 & +7 \\
2004 & 1 & 2 Aug 2004 & 1031 & -47 \\
2005 & 2 & 10 Aug 2005 & 934 & -144 \\
2006 & 3 & & 1427 & +349 \\
2007 & 4 & & 831 & -247 \\
2008 & 5 & 9 Sep 2008 & 1158 & +80 \\
\hline
\end{tabular}

trate the soil was recorded to the nearest second up to 5 minutes.

A hand-held tension infiltrometer (Mini Disk Infiltrometer, Meter Group formerly Decagon Devices, Pullman, WA) was used to assess a relative infiltration rate $\left(\mathrm{mL} \mathrm{min}^{-1}\right)$ (Robichaud et al., 2008). The short time used for the test, the small contact area of the infiltration disk $\left(\sim 800 \mathrm{~mm}^{2}\right)$, and the unconfined area of infiltration under the disk makes it difficult to directly compare the infiltration measured in this test to infiltration rates measured over longer times with more controlled conditions and sophisticated equipment-hence the term "relative infiltration rate". With the mini-disk infiltrometer set to $1-\mathrm{cm}$ of tension, the relative infiltration rate was defined as the amount of water leaving the device in one minute of contact with the soil, and the mean of three repetitions was calculated at each depth. For reference, Robichaud et al. (2008) established that the relative infiltration rate correlated to soil water repellency classes (as measured by the WDPT test) as: a) $\geq 8 \mathrm{~mL} \min ^{-1}$ (WDPT 0 to $5 \mathrm{~s}$ ) $=$ no repellency; b) 3 to $<8 \mathrm{~mL} \mathrm{~min}^{-1}$ (WDPT 6 to $180 \mathrm{~s})=$ weak to moderate repellency; and c) 0 to $<3 \mathrm{~mL}$ $\min ^{-1}$ (WDPT 181 to $300 \mathrm{~s}$ ) = strong repellency.

\section{Rainfall simulation}

The rainfall simulation equipment and procedures used in Robichaud et al. (2016) were nearly identical to this study. Rainfall was applied to each plot at a continuous rainfall intensity of $100 \mathrm{~mm} \mathrm{~h}^{-1}$ (median $=100.6 \mathrm{~mm} \mathrm{~h}^{-1}$ ) for one hour using a US Department of Agriculture Forest Service-modified Purdue-type $90^{\circ}$ arc oscillating-nozzle rainfall simulator with specifications from Meyer and Harmon (1979). The application rate was approximately equal to the rainfall intensity of a $10-\mathrm{min}$ rainfall event with a 5- to 10-year return period (Hanson and Pierson, 2001) adjusted for elevation (Bonnin et al., 2006) as well as exceeding the infiltration rate for the unburned forest condition (Robichaud, 2000).

Prior to each simulation, the rainfall was collected in a calibration pan covering the plot and measured with a graduated cylinder. The flow rate to the nozzles was adjusted so that the same per-unit-surface area rainfall rate was applied by repeating the calibration process if the slope-adjusted rainfall rate differed from the target rate by more than $5 \%$. The oscillating nozzle allowed for a more intermittent simulated rainfall similar to natural rainfall with comparable velocity, drop size and intensity (Bertrand and Parr, 1961). A 3-m tall wind skirt was wrapped around the simulator to prevent wind interaction with the rainfall (Meyer and Harmon, 1979).

Each $0.5 \mathrm{~m}^{2}$ rainfall simulation plot was delineated by a sheet metal frame with $15-\mathrm{cm}$ tall sides, with $5 \mathrm{~cm}$ of each side extended into the soil. A covered tray at the downhill end of the frame captured runoff at the ground surface and routed the runoff into a pipe used for sampling. During the 60-min rainfall simulation, timed runoff samples were collected every minute for the first 16 minutes and every two minutes thereafter. If necessary, sample times were adjusted so that samples would 
Table 2. Median values of ground cover, soil moisture, relative infiltration, and water drop penetration time (WDPT) reported by treatment, slope, and calendar year (post-fire year in parenthesis) $\cdot \bullet=$ no data. Infiltration and water repellency median values are further divided by depth $(\mathrm{cm})$ of measurement. $95 \%$ confidence limits are shown in brackets. Within each column, different letters indicate a significant difference $(\alpha=0.05)$.

\begin{tabular}{|c|c|c|c|c|c|c|c|c|c|c|c|c|c|c|c|c|c|}
\hline \multirow[b]{2}{*}{ Site } & \multirow{2}{*}{ Year } & \multirow{2}{*}{\multicolumn{2}{|c|}{$\begin{array}{l}\text { Ground cover } \\
(\%)\end{array}$}} & \multirow{2}{*}{\multicolumn{2}{|c|}{$\begin{array}{l}\text { Soil moisture } \\
\left(\mathrm{m}^{3} \mathrm{~m}^{-3}\right)\end{array}$}} & \multicolumn{6}{|c|}{ Relative infiltration $\left(\mathrm{ml} \mathrm{min}^{-1}\right)$} & \multicolumn{6}{|c|}{ WDPT test (s) } \\
\hline & & & & & & Surface & & $1 \mathrm{~cm}$ & & $3 \mathrm{~cm}$ & & Surface & & $1 \mathrm{~cm}$ & & $3 \mathrm{~cm}$ & \\
\hline 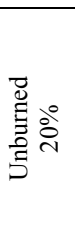 & $\begin{array}{l}2003(0) \\
2004(1)\end{array}$ & $\begin{array}{l}67 \\
{[35-81]} \\
61 \\
{[26-80]} \\
58 \\
{[9-66]} \\
100 \\
{[95-100]} \\
\end{array}$ & $\begin{array}{l}\text { bcd } \\
\text { cde } \\
\text { de }\end{array}$ & $\begin{array}{l}0.20 \\
{[0.13-0.38]} \\
0.12 \\
{[0.05-0.18]} \\
0.14 \\
{[0.09-0.20]} \\
0.11 \\
{[0.05-0.22]} \\
\end{array}$ & $a b c$ & $\begin{array}{l}7 \\
{[5-9]} \\
4 \\
{[1-7]} \\
1 \\
{[0-8]} \\
0\end{array}$ & $\begin{array}{l}\text { bcd } \\
\text { cde }\end{array}$ & $\begin{array}{l}7 \\
{[2-12]} \\
5 \\
{[1-9]} \\
12 \\
{[4-16]} \\
\end{array}$ & $\begin{array}{l}a b c \\
c \\
a b c\end{array}$ & $\begin{array}{l}7 \\
{[4-14]} \\
10 \\
{[6-16]} \\
8 \\
{[5-13]}\end{array}$ & $a b c$ & $\begin{array}{l}5 \\
{[2-27]} \\
90 \\
{[16-125]} \\
270 \\
{[90-300]} \\
\cdot\end{array}$ & $\begin{array}{l}\text { cdef } \\
\text { abcd } \\
\text { ab }\end{array}$ & $\begin{array}{l} \\
15 \\
{[2-70]} \\
44 \\
{[22-138]} \\
1 \\
{[1-7]} \\
\end{array}$ & $\begin{array}{l}\text { bcde } \\
\text { abc } \\
\text { de }\end{array}$ & $\begin{array}{l}0 \\
{[0-3]} \\
1 \\
{[0-25]} \\
2 \\
{[1-13]}\end{array}$ & $\begin{array}{l}\text { e } \\
\text { de } \\
\text { cde }\end{array}$ \\
\hline $\begin{array}{l}\text { 总 } \\
\text { 言 } \\
\text { s. }\end{array}$ & $\begin{array}{l}2003(0) \\
2004(1) \\
2005(2)\end{array}$ & $\begin{array}{l}94 \\
{[80-97]} \\
88 \\
{[70-93]} \\
87 \\
{[74-95]} \\
95 \\
{[85-98]} \\
\end{array}$ & $\begin{array}{l}\text { abcd } \\
a b c \\
a\end{array}$ & $\begin{array}{l}0.15 \\
{[0.05-0.27]} \\
0.03 \\
{[0.02-0.06]} \\
0.04 \\
{[0.02-0.06]} \\
0.04 \\
{[0.02-0.09]^{\mathrm{e}}}\end{array}$ & def & $\begin{array}{l}4 \\
{[2-5]} \\
2 \\
{[0-19]} \\
1 \\
{[0-2]} \\
\bullet\end{array}$ & cde & $\begin{array}{l}3 \\
{[2-13]} \\
6 \\
{[2-13]} \\
12 \\
{[7-14]} \\
\end{array}$ & $\begin{array}{l}\mathrm{bc} \\
\mathrm{abc} \\
\mathrm{abc}\end{array}$ & $\begin{array}{l}6 \\
{[2-11]} \\
5 \\
{[1-13]} \\
14 \\
{[7-27]} \\
\end{array}$ & $\begin{array}{l}a b c \\
a\end{array}$ & $\begin{array}{l}18 \\
{[0-149]} \\
163 \\
{[1-300]} \\
269 \\
{[174-300]} \\
\cdot\end{array}$ & $\begin{array}{l}\text { bcde } \\
\text { abc } \\
\text { a }\end{array}$ & $\begin{array}{l}75 \\
{[1-128]} \\
101 \\
{[4-271]} \\
2 \\
{[1-41]} \\
\end{array}$ & $\begin{array}{l}\text { abcd } \\
\text { abc } \\
\text { cde }\end{array}$ & $\begin{array}{l}5 \\
{[1-43]} \\
32 \\
{[1-205]} \\
1 \\
{[1-15]} \\
\end{array}$ & $\begin{array}{l}\text { abcde } \\
\text { abcd } \\
\text { cde }\end{array}$ \\
\hline 营 & $\begin{array}{l}2004(1) \\
2005(2) \\
2008(5)\end{array}$ & $\begin{array}{l}1 \\
{[0.05-1]} \\
1 \\
{[0.05-4]} \\
2 \\
{[0.05-9]} \\
6 \\
{[3-28]}\end{array}$ & $\begin{array}{l}\mathrm{h} \\
\mathrm{fgh}\end{array}$ & $\begin{array}{l}0.07 \\
{[0.04-0.10]} \\
0.03 \\
{[0.02-0.06]} \\
0.04 \\
{[0.03-0.06]} \\
0.02 \\
{[0.01-0.05]^{\mathrm{e}}}\end{array}$ & bcd & $\begin{array}{l}0 \\
{[0-1]} \\
10 \\
{[5-14]} \\
12 \\
{[7-17]} \\
15 \\
{[12-19]}\end{array}$ & $a b c$ & $\begin{array}{l}4 \\
{[0-6]} \\
3 \\
{[0-14]} \\
14 \\
{[9-16]}\end{array}$ & $\begin{array}{l}\mathrm{c} \\
\mathrm{ab}\end{array}$ & $\begin{array}{l}1 \\
{[0-4]} \\
2 \\
{[0-4]} \\
13 \\
{[0-16]}\end{array}$ & $\mathrm{bc}$ & $\begin{array}{l}300 \\
{[194-300]} \\
1 \\
{[0-38]} \\
3 \\
{[1-38]} \\
1 \\
{[0-1]}\end{array}$ & $\begin{array}{l}\text { efg } \\
\text { defg } \\
\text { efg }\end{array}$ & $\begin{array}{l}158 \\
{[16-300]} \\
236 \\
{[104-300]} \\
1 \\
{[0-6]}\end{array}$ & $\begin{array}{l}\text { a } \\
\text { de }\end{array}$ & $\begin{array}{l}263 \\
{[10-300]} \\
133 \\
{[17-300]} \\
2 \\
{[1-269]}\end{array}$ & $\begin{array}{l}\mathrm{a} \\
\mathrm{ab} \\
\text { bcde }\end{array}$ \\
\hline 营 & $\begin{array}{l}2004(1) \\
2005(2)\end{array}$ & $\begin{array}{l}1 \\
{[0.5-3]} \\
1 \\
{[0.5-3]} \\
1 \\
{[0-4]} \\
8 \\
{[5-20]} \\
\end{array}$ & ef & $\begin{array}{l}0.03 \\
{[0.02-0.07]} \\
0.04 \\
{[0.01-0.07]} \\
0.05 \\
{[0.04-0.08]} \\
0.02 \\
{[0.02-0.05]} \\
\end{array}$ & cde & $\begin{array}{l}1 \\
{[0-3]} \\
8 \\
{[6-13]} \\
17 \\
{[11-23]} \\
17 \\
{[8-20]} \\
\end{array}$ & $\begin{array}{l}\text { abcd } \\
\mathrm{a}\end{array}$ & $\begin{array}{l}3 \\
{[2-7]} \\
5 \\
{[1-8]} \\
15 \\
{[11-20]} \\
\end{array}$ & $\begin{array}{l}\mathrm{c} \\
\mathrm{a}\end{array}$ & $\begin{array}{l}1 \\
{[0-2]} \\
1 \\
{[0-3]} \\
12 \\
{[5-16]} \\
\end{array}$ & $\mathrm{a}$ & $\begin{array}{l}224 \\
{[153-300]} \\
1 \\
{[0-46]} \\
0 \\
{[0-1]} \\
1 \\
{[0-1]} \\
\end{array}$ & $\begin{array}{l}\text { efg } \\
\mathrm{g} \\
\mathrm{fg}\end{array}$ & $\begin{array}{l}82 \\
{[7-201]} \\
67 \\
{[8-205]} \\
1 \\
{[0-2]} \\
\end{array}$ & $\begin{array}{l}a b c \\
a b c\end{array}$ & $\begin{array}{l}142 \\
{[4-269]} \\
38 \\
{[5-300]} \\
1 \\
{[0-35]} \\
\end{array}$ & $\begin{array}{l}a b \\
a b c \\
\text { cde }\end{array}$ \\
\hline
\end{tabular}

fit in a 1-L bottle. Sediment-laden water samples were weighed in the lab, dried, and re-weighed to obtain the sample runoff volume and the sediment concentration. The weight of any residual sediment in the tray was also dried and included in the total sediment yield for each rainfall simulation.

Total infiltration was calculated by subtracting the total runoff from the total applied rainfall (rainfall rate multiplied by horizontal plot area). The infiltration amount was also calculated for the first 3-, 5-, and 10-minutes of the simulation so that these values could be correlated to mini-disk infiltrometer measurements.

\section{Statistical analysis}

Most variables collected reflected non-normal and nontransformable distributions, therefore, nonparametric statistical methods were used (Corder and Foreman, 2009; R Core Team, 2013) by calculating medians (Corder and Foreman, 2009) and the $95 \%$ nonparametric (distribution-free) confidence intervals (Hollander and Wolfe, 1999; R Core Team, 2013). It was assumed that unburned plots were spatially close enough to the burned plots to be representative of the burned areas prior to the fire. Significant differences between years, slopes and treatment were analyzed using Kruskal-Wallis comparisons based on rank (Conover, 1999; Corder and Foreman, 2009; R Core Team, 2013). Multiple comparisons were conducted using the post-hoc tests in the Kruskal function in the R package "agricolae" (Conover, 1999; R Core Team, 2013). The Benjamini and Hotchberg false discovery rate correction was used to adjust the p-values to minimize type I errors for multiple comparison tests (Benjamini and Hochberg, 1995). Spearman correlation coeffi- cients were calculated to determine significant relationships between all variables (Conover, 1999; Corder and Foreman, 2009; R Core Team, 2013). All tests were considered significant at $\alpha=0.05$. A ratio of infiltration on the burned sites to infiltration on the unburned sites was calculated for both the relative infiltration values as measured by the mini-disk infiltrometer and the actual infiltration values from the rainfall simulation for each year.

\section{RESULTS}

\section{Site characteristics}

Nearly $100 \%$ of the ground cover was consumed on severely burned portions of the Hot Creek Fire, and consequently, vegetation recovery was slow on the burned plots during the five years of monitoring. By post-fire year five, median ground cover on the burned sites was $7 \%$ compared to $95-100 \%$ on the unburned sites (Table 2). Ground cover varied on the unburned plots in the first three years of the study, and was slightly lower on the $20 \%$ unburned plots $(60-70 \%)$ compared to the $60 \%$ unburned plots $(\sim 90 \%)$ (Table 2$)$.

Soil moisture in the fire year was lower on the burned sites (0.03-0.07, Table 2) compared to the unburned sites (0.15$0.20)$. After the first year, soil moisture was consistently greater on the $20 \%$ slope unburned site $(0.11-0.14)$ than all other sites $(0.02-0.05)$, likely due to nearby ground water seeps. The lack of cover and a possible increase in soil water evaporation may have also contributed to low soil moisture on the burned sites. Varying degrees and depths of soil water repellency as well as reduced relative infiltration were found on both the burned and unburned sites in the first two post-fire years (Table 2). 
Table 3. Spearman correlation coefficients between relative infiltration values $\left(\mathrm{mL} \mathrm{min}^{-1}\right)$ and WDPT values $(\mathrm{s})$ are shown for surface, $1-\mathrm{cm}$ and $3-\mathrm{cm}$ depths using data from all years-all treatments and using data from all years-burned sites only. Correlations are all negative because as infiltration decreases, WDPT values increase. $p<0.0001$ for all values.

\begin{tabular}{lllll}
\hline & \multicolumn{2}{l}{ All years- } & \multicolumn{2}{l}{ All years- } \\
& \multicolumn{2}{l}{ all treatments } & \multicolumn{2}{c}{ burned only } \\
Depth $(\mathrm{cm})$ & $n$ & $\rho$ & $n$ & $\rho$ \\
\hline Surface & 138 & -0.83 & 78 & -0.69 \\
1 & 122 & -0.68 & 61 & -0.77 \\
3 & 120 & -0.78 & 60 & -0.84 \\
\hline
\end{tabular}

Relative infiltration rate was significantly correlated $(p<0.0001)$ with WDPT measurements at all depths and over all years and treatments ( $\rho=-0.77$ to -0.84 , Table 3 ).

In the fire year (2003), the mineral soil surface was strongly water repellent (WDPT $>180 \mathrm{~s}$, relative infiltration rate $<3 \mathrm{~mL}$ $\min ^{-1}$ ) on burned sites, but was wettable to only slightly water repellent on unburned sites (WDPT $<60 \mathrm{~s}$, relative infiltration rate $>3 \mathrm{~mL} \mathrm{~min}^{-1}$ ). On burned plots in post-fire years one and two (2004 and 2005), soil water repellency and reduced infiltration was moderate to strong at soil depths of $1-$ and $3-\mathrm{cm}$ and absent at the mineral soil surface when surface measurements were taken (Table 2). In contrast, water repellency and relative infiltration rate on unburned soils in post-fire years one and two generally exhibited moderate to strong repellency at the mineral surface, slight to moderate repellency at $1-\mathrm{cm}$ depth and wettable to slightly repellent conditions at 3-cm depth (Table 2). No repellency or reduced infiltration was measured at any of the sites or depths in the fifth post-fire year (2008).

The differences between the $20 \%$ and $60 \%$ slope sites (both burned and unburned) were varied and unpredictable. Through the first two post-fire years, ground cover was lower on the $20 \%$ slope unburned site than the $60 \%$ slope unburned site, despite having statistically higher soil moisture in post-fire years 1 and 2 (but not the year of the fire). In the final year of our study, soil moisture was still higher on the $20 \%$ slope unburned site than the $60 \%$ slope unburned site, and both sites had nearly $100 \%$ ground cover (Table 2 ).

Soil water repellency and relative infiltration were similar on the $20 \%$ and $60 \%$ slope unburned sites at comparable depths over all years. Total infiltration was significantly greater for the unburned $20 \%$ slope plots than the unburned $60 \%$ slope plots through the first post-fire year. These differences in cover and soil properties suggest some inherent site differences between the two unburned sites, which highlights the importance of spatial scale when measuring or predicting watershed characteristics.

\section{Rainfall simulation}

The fire significantly decreased total infiltration on the $20 \%$ burned plots (Table 4). The infiltration rates for simulated rainfall on $20 \%$ slope burned plots were one third that for unburned conditions through two post-fire years (2003-2005; Figure 2). In contrast, burning did not significantly reduce infiltration rate or total infiltration on $60 \%$ slope plots (Table 4 , Figure 2). By the fifth post-fire year (2008), median total infiltration ranged from $62-83 \mathrm{~mm}$ on all plots, with the exception of $20 \%$ slope burned plots $(27 \mathrm{~mm})$.

Interrill erosion sediment yield from burned rainfall simulation plots increased after fire by at least 10 to 100 times on both $60 \%$ and $20 \%$ slopes, respectively, compared to their unburned counterparts (Table 4). Through the first post-fire year, sediment yield from 20\% slope burned plots (1900-2214
Table 4. Median values of total infiltration $(\mathrm{mm})$ and total sediment $\left(\mathrm{g} \mathrm{m}^{-2}\right)$ from rainfall simulations reported by treatment, slope, and calendar year (post-fire year in parenthesis). Each value is calculated from $n=10$ samples, unless indicated otherwise. Within each column and variable, different letters indicate a significant difference $(\alpha=0.05)$. 95\% confidence limits are shown in brackets.

\begin{tabular}{|c|c|c|c|c|c|}
\hline Site & Year & $\begin{array}{l}\text { Total infiltr } \\
(\mathrm{mm})\end{array}$ & & $\begin{array}{l}\text { Total sediment } \\
\left(\mathrm{g} \mathrm{m}^{-2}\right)\end{array}$ & \\
\hline \multirow{4}{*}{ 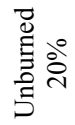 } & $2003(0)$ & 61 [49-97] & $a b c$ & $8[2-34]$ & ef \\
\hline & $2004(1)$ & 67 [55-91] & $a b$ & $7[5-17]$ & ef \\
\hline & $2005(2)$ & 70 [49-98] & $a b$ & $5[0.4-11]$ & $\mathrm{f}$ \\
\hline & $2008(5)$ & 83 [69-97] & $\mathrm{a}$ & $3[2-11]$ & $\mathrm{f}$ \\
\hline \multirow{4}{*}{ 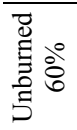 } & $2003(0)$ & $35[28-44]$ & de & 57 [23-139] & $\mathrm{d}$ \\
\hline & $2004(1)$ & 42 [37-49] & cde & $40[16-93]$ & $\mathrm{d}$ \\
\hline & $2005(2)$ & $45[36-70]$ & bcd & 39 [15-162] & $\mathrm{d}$ \\
\hline & $2008(5)^{\mathrm{a}}$ & $73[70-91]$ & $\mathrm{a}$ & 35 [25-147] & de \\
\hline \multirow{4}{*}{ 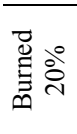 } & $2003(0)$ & $20[13-26]$ & $\mathrm{g}$ & 1900 [1307-2249] & $\mathrm{ab}$ \\
\hline & 2004 (1) & $18[15-24]$ & g & $2214[1725-2656]$ & $a b$ \\
\hline & $2005(2)$ & $19[15-31]$ & fg & 1698 [1305-2306] & $\mathrm{ab}$ \\
\hline & $2008(5)^{\mathrm{a}}$ & $27[23-59]$ & efg & 329 [182-902] & $\mathrm{cd}$ \\
\hline \multirow{4}{*}{ 总 } & $2003(0)$ & $33[32-36]$ & de & $2151[1726-2586]$ & $\mathrm{ab}$ \\
\hline & $2004(1)$ & $33[32-36]$ & def & 2356 [1957-2996] & $\mathrm{a}$ \\
\hline & $2005(2)$ & $33[31-40]$ & de & 2532 [1910-3193] & $\mathrm{a}$ \\
\hline & $2008(5)$ & $62[48-83]$ & $a b c$ & $1200[372-2152]$ & $\mathrm{bc}$ \\
\hline
\end{tabular}

${ }^{\mathrm{a}}$ Only 8 values were used in calculations.
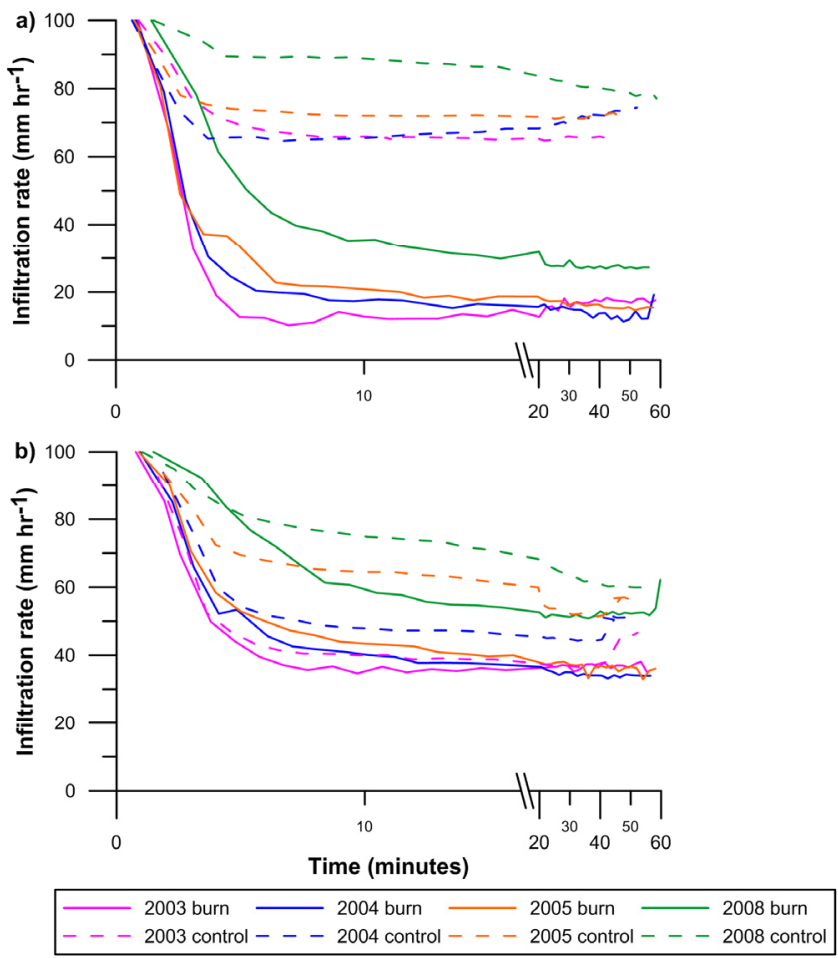

Fig. 2. Infiltration rate versus time for the rainfall simulator experiments on burned and control sites on a) $20 \%$ slope plots and b) $60 \%$ slope plots, in the year of the fire (2003), post-fire year 1 (2004), post-fire year 2 (2005), and post-fire year 5 (2008).

$\mathrm{g} \mathrm{m}^{-1}$ ) and $60 \%$ slope burned plots (2151-2356 $\mathrm{g} \mathrm{m}^{-1}$ ) was similar. However, by post-fire year five (2008), there was onequarter less sediment on the $20 \%$ slope burned plots $\left(329 \mathrm{~g} \mathrm{~m}^{-1}\right)$ than the $60 \%$ slope burned plots $\left(1200 \mathrm{~g} \mathrm{~m}^{-1}\right)$. Over all years and plots $(n=156)$, slope had a low, yet significant positive correlation to sediment yield $(\rho=0.26 ; p=0.001)$.

Over the study period, sediment yields on the burned sites decreased as ground cover returned and soils stabilized. Total sediment was correlated to ground cover over all years and plots at $\rho=-0.73(p<0.0001)$. Although sediment decreased 
Table 5. Correlation coefficients $(\rho)$ between relative infiltration values as measured at the surface, $1-\mathrm{cm}$ and 3 -cm depths and total infiltration values as measured at 3-, 5-, and 10-min in the rainfall simulation and final infiltration (60 min). Correlations for data from all yearsall treatments and for data from all years-burned sites only are shown.

\begin{tabular}{|c|c|c|c|c|c|c|c|c|}
\hline \multirow[b]{2}{*}{ Depth $(\mathrm{cm})$} & \multicolumn{4}{|c|}{ All years - all treatments } & \multicolumn{4}{|c|}{ All years - burned only } \\
\hline & $3 \mathrm{~min}$ & $5 \mathrm{~min}$ & $10 \mathrm{~min}$ & $60 \mathrm{~min}$ & $3 \mathrm{~min}$ & $5 \mathrm{~min}$ & $10 \mathrm{~min}$ & $60 \mathrm{~min}$ \\
\hline Surface & $0.20^{*}$ & 0.15 & 0.10 & -0.11 & $0.33^{*}$ & $0.33^{*}$ & $0.39^{*}$ & $0.31^{*}$ \\
\hline 1 & $0.40^{* *}$ & $0.48^{* *}$ & $0.49^{* *}$ & $0.32^{*}$ & $0.51^{*}$ & $0.60^{* *}$ & $0.60^{* *}$ & $0.48^{*}$ \\
\hline 3 & $0.30^{*}$ & $0.50^{* *}$ & $0.52^{* *}$ & $0.57^{* *}$ & $0.28^{*}$ & $0.42^{*}$ & $0.46^{*}$ & $0.37^{*}$ \\
\hline
\end{tabular}

during the study, the decrease was statistically significant only between post-fire year two and post-fire year five (Table 4) when sediment decreased by $80 \%$ on the $20 \%$ burned site and by half on the $60 \%$ burned site. By post-fire year five, sediment produced on the burned sites (329-1200 $\mathrm{g} \mathrm{m}^{-1}$ ) was still orders of magnitude greater than unburned sites (3-35 $\mathrm{g} \mathrm{m}^{-1}$, Table 4). Sediment yields were similar within a slope class on unburned sites in all years (Table 4); however, there was significantly less sediment on the $20 \%$ slope plots than on the $60 \%$ slope plots in every year regardless of burn.

In the year of the fire alone, relative infiltration (measurements made with a mini-disk infiltrometer) taken at the soil surface were significantly correlated to total infiltration from the rainfall simulation when all treatments were pooled $(\rho=$ $0.67 ; p<0.0001$ ) (data not shown). As relative infiltration increased, total infiltration increased. When all years were considered, relative infiltration measurements taken at $1-$ or $3-\mathrm{cm}$ depth were more indicative of total infiltration than those taken at the soil surface (Table 5). In general, greater relative infiltration values below the soil surface indicated an increase in total infiltration over all years and plots.

The ratio analysis comparing relative infiltration at 1- and 3$\mathrm{cm}$ depths to total infiltration indicated similarly trending values over time (Figure 3 ). In the year of the fire there was much less infiltration on the burned $20 \%$ slope plots compared to the control plots $($ ratio $=0.3$ ) (Figure 3a), while infiltration was nearly equivalent on the $60 \%$ slope plots (ratio $=0.97$ ). In 2004 and 2005 infiltration was lower on all burned plots than on control plots, which were measured both by rainfall simulation and the mini-disk infiltrometer measurements (Figure 3). In the fifth post-fire year (2008), mini-disk infiltrometer relative infiltration measurements suggest recovery to pre-fire (unburned) levels, while rainfall simulation showed continued reduced infiltration on the burned plots, particularly on the $20 \%$ slope site.

To evaluate our ability to associate relative infiltration as measured by the mini-disk infiltrometer with non-steady state infiltration amounts, we calculated correlations at 3-, 5-, and 10-min into the hour-long rainfall simulations. The strongest relationships were found between the $1-\mathrm{cm}$ relative infiltration measures at 5- or 10-min into the rainfall simulation on the burned plots $(\rho=0.6 ; p<0.0001$, Table 5). Slightly weaker yet significant correlations $(\rho=0.4-0.5 ; p<0.001)$ were found at the $3-\mathrm{cm}$ depth at the same time periods. When all treatments were pooled, relative infiltration rate measurements taken at 1and 3-cm depth were also significantly correlated $(\rho=0.3-0.5)$ with total infiltration (Table 5).

\section{DISCUSSION}

\section{Trends in site recovery}

One of the most startling impacts of the Hot Creek Fire was the extremely slow recovery of vegetation in the high severity burned areas included in this study. Generally, most burned areas in western US mountain regions exhibit significant vege-

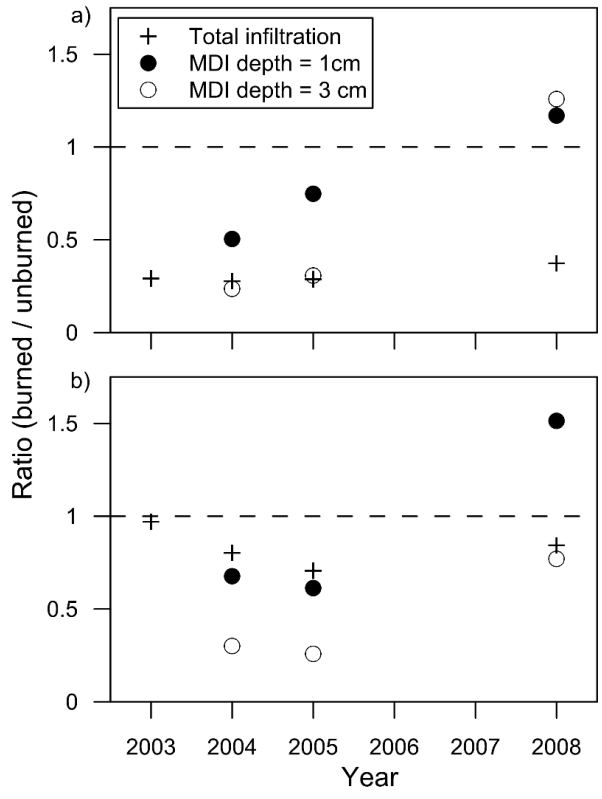

Fig. 3. Ratio of burned to unburned (control) infiltration values for total infiltration from the rainfall simulation and for relative infiltration measured with the mini-disk infiltrometer (MDI) on a) $20 \%$ slope plots, and b) $60 \%$ slope plots. 2003 was the year of the fire, post-fire year 1 (2004), post-fire year 2 (2005), and post-fire year 5 (2008). Values below the dashed line indicate less infiltration on the burned plots compared to the unburned plots; ratios increase over time as infiltration returns to unburned levels.

tation recovery by post-fire year five, although they can take up to 13 years or more to fully return to pre-fire levels (DeBano et al., 1996; Goetz et al., 2006; Robichaud et al., 2013a). Given that $60-70 \%$ natural ground cover is needed to effectively decrease erosion (Benavides-Solorio and MacDonald, 2005; Pannkuk and Robichaud, 2003; Wine et al., 2012), the less than $10 \%$ median ground cover in post-fire year 5 on the burned sites in our study (compared to $95-100 \%$ on the unburned sites) provided little protection from erosion. Slow vegetative recovery is usually attributed to low rainfall; however, annual and growing season (April through September) precipitation over monitoring years was not largely different from the mean precipitation prior to the fire (Table 1). The extremely slow recovery of vegetation observed in this study is more likely due to unusually high soil burn severity, and the subsequent loss of soil and surface cover due to wind- and water-driven erosion. It is probable that the fire intensity and severity of the Hot Creek Fire sterilized the soil, and possibly the seed bank, thus limiting various regeneration strategies of plant growth in the area (Graham, 2015; Mataix-Solera et al., 2009; Ryan, 2002). The sites most likely experienced intense crown and ground fire due to pre-heated dry fuels resulting in soil temperatures that exceeded $120^{\circ} \mathrm{C}$. Such intense soil heating generally kills viable seeds and underground rhizomes from which post-fire vegetative 
regrowth normally occurs (Ryan, 2002). It is also possible that the strong soil water repellency reported immediately after the fire and through post-fire year two also decreased the vegetative survival by decreasing infiltration especially in the summer as the soil dries and water repellency is enhanced (Madsen et al., 2012).

In the year of the fire, there was significantly higher soil water repellency on the soil surface of the burned sites than the unburned sites. Although we did not sample water repellency or relative infiltration below the soil surface in the year of the fire, we likely would have measured strong water repellency and reduced infiltration deeper into the soil profile (Doerr et al., 2000) as we did in subsequent years of the study (Table 2). At the scale of our measurements, soil water repellency contributed to reduced infiltration rates (DeBano, 1971; Doerr et al., 2009b). This reduced infiltration combined with loss of soil structure and ground cover from the high severity fire led to greater interrill erosion and subsequent greater sediment yields on the burned plots throughout the study period.

The unburned sites exhibited natural, or inherent, water repellency intermittently throughout the study period, particularly on the soil surface (Doerr et al., 2009a), where water repellency was sometimes greater on the unburned than on the burned sites (Table 2). Inherent soil water repellency is characteristic of the ash cap soils in the study area (Doerr et al., 2009a; Kawamoto et al., 2007; Robichaud et al., 2016). In a previous study on the Hot Creek Fire, moderate levels of water repellency were measured through post-fire recovery year five (Robichaud et al., 2013a). While we did not measure any soil water repellency in the fifth year on the plots in this study, we attribute this inconsistency to site differences (e.g., aspect, soil moisture, soil organic matter).

The high severity burned sites exhibited significantly less vegetation and lower relative infiltration, somewhat lower total infiltration, and increased sediment yield compared to the unburned sites; however all values trended toward unburned site values over time. Measurements of soil water repellency, relative infiltration rate and ground cover were aggregately good indicators of infiltration and interrill sediment yields. It was difficult to separate the effects of any one factor, as they are not independent and tend to confound one another. This is consistent with previous post-fire studies that have shown high correlations among these factors (Benavides-Solorio and MacDonald, 2001; Robichaud et al., 2013a; Shakesby et al., 1993) and was also consistent with previous studies where ground cover was the predominate indicator of infiltration and runoff on recovering burned sites (Benavides-Solorio and MacDonald, 2005; Johansen et al., 2001; Larsen et al., 2009; Robichaud et al., 2013a). Vieira et al. (2015) found stronger relationships between burn severity and sediment yields than with runoff, which is consistent with what we measured. The measured sediment yields were likely lower than typical hillslope erosion rates after fire as suggested by Williams et al. (2016), who states that runoff contributes to the formation of concentratedflow paths that would increase sediment yields above those measured in this study, where the concentrated-flow processes were not active.

The ratio of infiltration on burned to unburned sites was consistent with other literature and indicated a recovery trend towards pre-fire conditions (Figure 3 ). In the first and second post-fire years $(2004,2005)$, the ratio of total infiltration values was closer to relative infiltration measured at $1-\mathrm{cm}$ on the $60 \%$ slope plots $(\sim 0.6)$, and at $3-\mathrm{cm}$ on the $20 \%$ slope plots $(0.25)$. Martin and Moody (2001) reported a ratio of about 0.4 on burned mountainous sites in New Mexico and Colorado in the first four months after wildfire. On burned oak sites in Spain, Imeson et al. (1992) measured infiltration ratios of 0.3 to 0.5 for up to two years following fire, and Arend (1941) measured infiltration in the Missouri Ozarks (oak forests) which had a burned to unburned ratio of 0.6. By the fifth post-fire year (2008), the ratio of total and relative infiltration values at both depths were mostly greater than 1.0 , indicating a return to prefire (unburned) infiltration values at all sites. Interestingly, infiltration values measured by the MDI (but not the rainfall simulation) indicated greater infiltration on the burned sites compared to the unburned sites. This may be in part due to the destruction of the inherent soil water repellency due to the burning of the surface soil organic layers. The meta-analysis by Ebel and Martin (2017) reported upwards of 20 years for organic matter to recover to pre-fire levels in soil. The ability to estimate the difference in infiltration between burned and unburned sites with a mini-disk infiltrometer test is an important benefit for quick assessment of post-fire conditions.

\section{Slope effects}

On the burned areas, we observed varied microtopography of the soil surface between the $20 \%$ and $60 \%$ slope sites (Figures $4 \mathrm{a}, \mathrm{b}$ ). Large numbers of burned roots and displaced rocks created macropores on the $60 \%$ slope site that were not observed on the $20 \%$ slope site. These macropores could have increased infiltration by providing pathways for water to penetrate reducing overland flow, and subsequently decreased sediment yield by allowing places for sediment deposition within the plot. Cerdà and García-Fayos (1997) cited soil cracks and heterogeneous surfaces to be the controlling factors on infiltration, runoff, and sediment yields on sloped plots. Imeson et al. (1992) made similar observations, that on comparable slopes within their study "hydrological processes are structured by interactions with vegetation." Small plots are particularly prone to microtopographic- or point-differences because they do not have the benefit of the equalizing properties of an entire hillslope or watershed (Larsen et al., 2009). The burned 60\% slope plots had greater infiltration as compared to the $20 \%$ burned plots, but the $60 \%$ burned plots also had greater sediment yields compared to the burned $20 \%$ slope site, especially in post-fire years two and five. This may indicate that the soil on the burned $60 \%$ site was more erodible than the soil on the burned $20 \%$ site or that the greater influence of gravity on the burned $60 \%$ slope site increased erosion as compared to the burned 20\% site (Scott et al., 2009).

\section{The use of relative infiltration measurements}

Relative infiltration rates, as measured by the mini-disk infiltrometer at $1-$ and $3-\mathrm{cm}$ were significantly correlated with the total infiltration measurements made during the first ten minutes (non-steady state) of the rainfall simulations (Table 5). This early period of the $60-\mathrm{min} 100 \mathrm{~mm} \mathrm{~h}^{-1}$ rainfall simulation (Figure 2) provides a reasonable facsimile of the short-duration, high-intensity convective rain storms (i.e., not long enough to reach steady-state infiltration) that are fairly typical in the Rocky Mountains and often cause the most runoff and erosion in post-fire environments (Robichaud et al., 2016; Wondzell and King, 2003). Thus, knowing the potential infiltration rate for such a rainstorm would allow for more accurate post-fire erosion modeling. From the data analyzed in this study, it seems reasonable that mini-disk measurements of relative infiltration could be transformed into total infiltration values, or at the very least, a ratio of infiltration reduction that could then be 

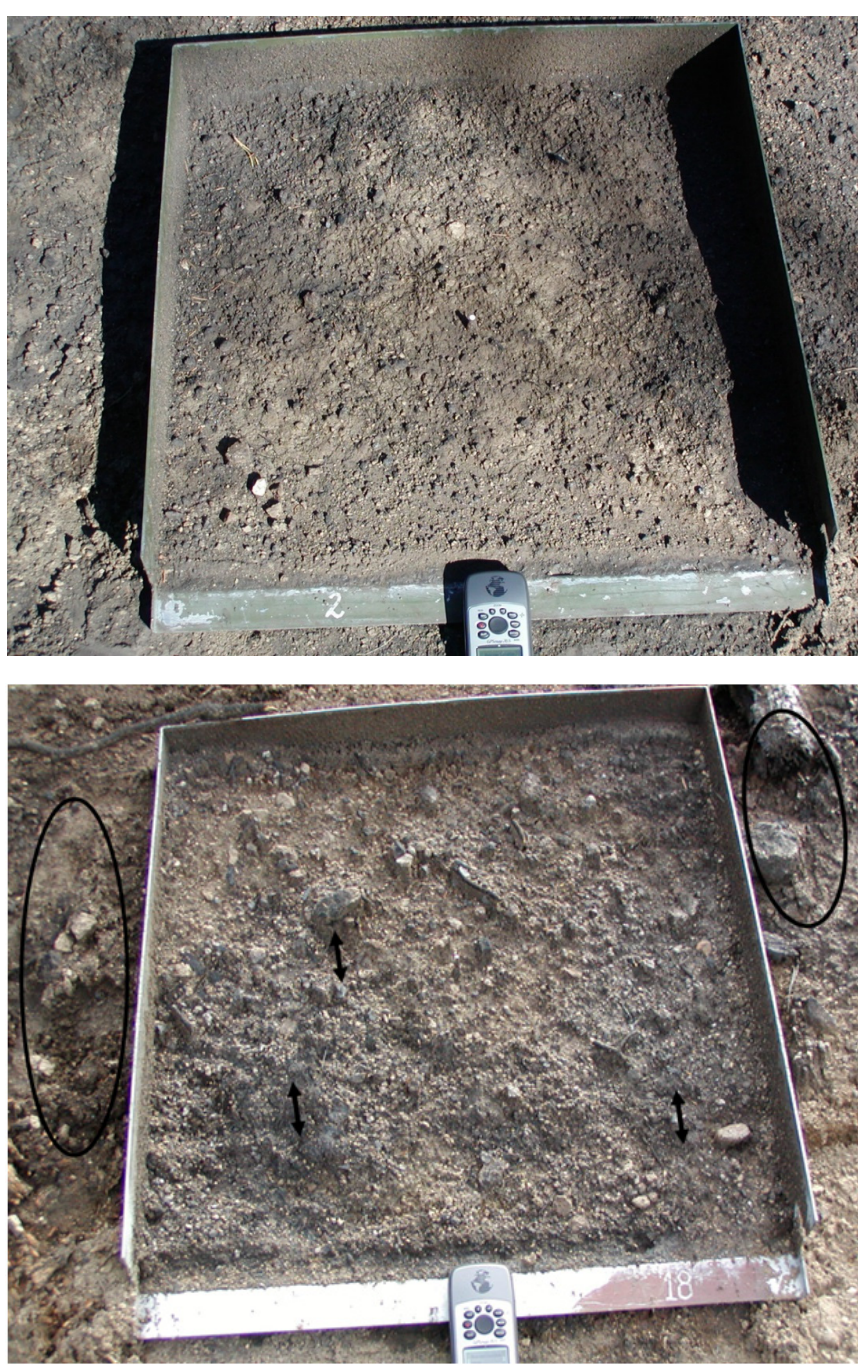

Fig. 4. Example plots from a) the burned $20 \%$ site, and b) the burned $60 \%$ site. The metal plot frames delineate the $0.5 \mathrm{~m}^{2}$ plot area from which the runoff and sediment samples were taken. Black ovals on b) show the rocks and stumps on site which can indicate macropores and increased ponding, while arrows highlight the rougher soil surface texture which slows surface flow and may increase infiltration.

used within various prediction models, such as the Erosion Risk Management Tool (ERMiT; Robichaud et al., 2007). Modeling post-fire erosion is most beneficial to land managers for determining downstream impacts and where erosion mitigation treatments are most likely needed (Elliott, 2013; Moody et al., 2013).

\section{CONCLUSION}

The Hot Creek Fire study area experienced a slow and incomplete return to pre-fire vegetation cover and infiltration conditions during our five-year study. Ground cover was remarkably low on all burned sites through post-fire year five; consequently, runoff and interrill erosion were elevated in all years on the burned sites compared to the unburned sites. Differences in site microtopography and burn characteristics between the burned $20 \%$ and $60 \%$ slope sites affected soil structure and composition, resulting in less infiltration and more runoff on the sites with low slopes than sites with steeper slopes. Over all burned sites, total infiltration rate decreased and sediment yield increased immediately after the fire and gradually trended toward unburned conditions in the years following the fire.

Relative infiltration rate measured with the mini-disk infiltrometer was significantly correlated to total infiltration and particularly non-steady state infiltration amounts. We conclude these relative measurements taken at shallow depths (1- to 3$\mathrm{cm}$ ) below the soil surface could be used to describe potential infiltration of a burned site during short-duration high-intensity storms and used in post-fire erosion models. Modelling postfire soil conditions and the resulting potential for increased runoff and sediment is an important task for land managers after wildfires.

Acknowledgements. This study was funded in part by the US Department of Interior and US Department of Agriculture Joint Fire Sciences Program. The authors would to acknowledge the contributions of field crews from the US Department of Agriculture, Forest Service, Rocky Mountain Research Station and Agricultural Research Service, Northwest Research Center and logical support from the Boise National Forest. Additional special thanks to Joseph Wagenbrenner for assistance in statistical analysis, and Louise Ashmun for providing critical comments on earlier drafts of the manuscript. We also thank two anonymous reviewers who provided comments that greatly improved the clarity of the manuscript.

\section{REFERENCES}

Agee, J.K., 1996. Fire Ecology of the Pacific Northwest Forests. Island Press, Washington DC, USA, $505 \mathrm{p}$.

Arend, J.L., 1941. Infiltration rates of forest soils in the Missouri Ozarks as affected by burning and litter removal. J. Forest., 39, 726-728.

Barrett, G., Slaymaker, O., 1989. Identification, characterization, and hydrological implications of water repellency in mountain soils, Southern British Columbia. Catena, 16, 4, 477-489. DOI: 10.1016/0341-8162(89)90029-5.

Benavides-Solorio, J.D., Macdonald, L.H., 2001. Post-fire runoff and erosion from simulated rainfall on small plots, Colorado Front Range. Hydrol. Process., 15, 2931-2952. DOI: 10.1002/hyp.383.

Benavides-Solorio, J.D., Macdonald, L.H., 2005. Measurement and prediction of post-fire erosion at the hillslope scale, Colorado Front Range. Int. J. Wildland Fire, 14, 4, 457-474. DOI: 10.1071/WF05042.

Benjamini, Y., Hochberg, Y., 1995. Controlling the false discovery rate: a practical and powerful approach to multiple testing. J. Roy. Stat. Soc. Series B Methology, 57, 1, 289-300.

Bertrand, A.R., Parr, J.F., 1961. Design and operation of the Purdue sprinkling infiltrometer. Research Bulletin No. 723. U.S. Department of Agriculture, Purdue University Agricultural Experiment Station, Lafayette, Indiana, USA.

Bonnin, G.M., Martin, D., Lin, B., Parzybok, T., Yekta, M., Riley, D., 2006. Precipitation frequency atlas of the United States. NOAA Atlas 14, Volume 1, Version 4. NOAA National Weather Service, Silver Spring, Maryland, USA.

Burch, G.J., Moore, I.D., Burns, J., 1989. Soil hydrophobic effects on infiltration and catchment runoff. Hydrol. Process., 3, 3, 211-222. DOI: 10.1002/hyp.3360030302.

Cerdà, A., 1996. Seasonal variability of infiltration rates under contrasting slope conditions in southeast Spain. Geoderma, 69, 3-4, 217-232. DOI: 10.1016/0016-7061(95)00062-3.

Cerdà, A., García-Fayos, P., 1997. The influence of slope angle on sediment, water and seed losses on badland landscapes. Geomorphology, 18, 77-90. DOI: 10.1016/S0169-555X(96)00019-0.

Cerdà, A., Robichaud, P.R., 2009. Fire effects on soil infiltration. In: Cerdà, A., Robichaud, P.R. (Eds.): Fire Effects on Soils and 
Restoration Strategies. Science Publishers, Enfield, New Hampshire, USA, pp. 81-103.

Conover, W.J., 1999. Practical Nonparametric Statistics. $3^{\text {rd }}$ ed. John Wiley \& Sons Inc., New York, New York, USA, 816 p.

Corder, G.W., Foreman, D.I., 2009. Nonparametric Statistics for Non-Statisticians: A Step-by-Step Approach. John Wiley \& Sons, Inc., Hoboken, New Jersey, USA, 264 p.

DeBano, L.F., 1971. The effect of hydrophobic substances on water movement in soil during infiltration. Soil Sci. Soc. Am. Proc., 35, 2, 340-343.

DeBano, L.F., 1981. Water repellent soils: a state-of-the-art. General Technical Report PSW-46. US Department of Agriculture, Forest Service, Pacific Southwest Forest and Range Experiment Station, Berkley, California, USA, $21 \mathrm{p}$.

DeBano, L.F., Ffolliott, P.F., Baker, M.B., 1996. Fire severity effects on water resources. In: Ffolliott, P.F., DeBano, L.F., Baker, Jr., M.B., Gottfried, G.J., Solis-Garza, G., Edminster, C.B., Neary, D.G., Allen, L.S., Hamre, R.H. (Eds.): Proc. Symp. Effects of fire on Madrean province ecosystems. General Technical Report RM-GTR-289. US Department of Agriculture, Forest Service, Rocky Mountain Forest and Range Experiment Station, Ft. Collins, Colorado, USA, pp. 77-84.

DeBano, L.F., Ffolliott, P.F., Neary, D.G., 1998. Fire's Effects on Ecosystems. John Wiley and Sons, Inc., New York, New York, USA, $352 \mathrm{p}$.

Decagon Devices, Inc. 2016. Mini disk infiltrometer manual, Ver. September 2, 2016. Decagon Devices Inc., Pullman, WA. Available

http://manuals.decagon.com/Manuals/10564 Mini\%20Disk\%20 Infiltrometer_Web.pdf (accessed 2 February 2017).

Doerr, S.H., Shakesby, R.A., Walsh, R.P.D., 2000. Soil water repellency: its causes, characteristics and hydro-geomorphological significance. Earth-Sci. Rev., 51, 33-65. DOI: 10.1016/S0012-8252(00)00011-8

Doerr, S.H., Shakesby, R.A., Blake, W.H., Chafer, C.J., Humphreys, G.S., Walbrink, P.J., 2006. Effects of differing wildfire severities on soil wettability and implications for hydrological response. J. Hydrol., 319, 1, 295-311. DOI: 10.1016/j.jhydrol.2005.06.038.

Doerr, S.H., Woods, S.W., Martin, D.A., Casimiro, M., 2009a. 'Natural background' soil water repellency in conifer forests of the north-western USA: Its prediction and relationship to wildfire occurrence. J. Hydrol., 371, 1-4, 12-21. DOI: 10.1016/j.jhydrol.2009.03.011.

Doerr, S.H., Shakesby, R.A., MacDonald, L.H., 2009b. Soil water repellency: a key factor in post-fire erosion. In: Cerdà, A., Robichaud, P.R. (Eds.): Fire Effects on Soils and Restoration Strategies. Science Publishers, Enfield, New Hampshire, USA, pp. 197-224.

Ebel, B.A., Martin, D.A., 2017. Meta-analysis of field-saturated hydraulic conductivity recovery following wildland fire: Applications for hydrologic model parameterization and resilience assessment. Hydrol. Process., 31, 3682-3696. DOI: 10.1002/hyp.11288.

Elliot, W.J., 2013. Erosion processes and prediction with WEPP technology in forests in the north-western US. T. ASABE, 56, 2, 563-579. DOI: 10.13031/2013.42680.

Elzinga, C.L., Salzer, D.W., Willoghby, J.W., 1998. Measuring and monitoring plant populations. Technical Reference 1730-1. Bureau of Land Management, US Department of the Interior, Denver, Colorado.

Goetz, S.J., Fiske, G.J., Bunn, A.G., 2006. Using satellite timeseries data sets to analyze fire disturbance and forest recovery across Canada. Remote Sens. Environ., 101, 3, 352-365. DOI: 10.1016/j.rse.2006.01.011.

Graham, R., 2015. Personal communication.

Hanson, C.L., Pierson, F.B., 2001. Characteristics of extreme precipitation and associated streamflow in the Reynolds Creek Experimental Watershed, Idaho. In: Proceedings of the 12th
Symposium on Global Climate Change. American Meteorological Society, Boston, MA, pp. J2.13-J2.16.

Hollander, M., Wolfe, D.A., 1999. Nonparametric Statistical Methods. $2^{\text {nd }}$ ed. John Wiley \& Sons, Inc., New York, New York, $816 \mathrm{p}$.

Hubbert, K.R., Preisler, H.K., Wohlgemuth, P.M., Graham, R.C., Narog, M.G., 2006. Prescribed burning effects on soil physical properties and soil water repellency in a steep chaparral watershed, Southern California, USA. Geoderma, 130, 3-4, 284-298. DOI: 10.1016/j.geoderma.2005.02.001.

Huffman, E.L., MacDonald, L.H., Stednick, J.D., 2001. Strength and persistence of fire-induced soil hydrophobicity under ponderosa and lodgepole pine, Colorado Front Range. Hydrol. Process., 15, 15, 2877-2892. DOI: 10.1002/hyp.379.

Ice, G.G., Neary, D.G., Adams, P.W., 2004. Effects of wildfire on soils and watershed processes. J. Forest., 102, 6, 15-20.

Imeson, A.C., Verstraten, J.M., van Mulligan, E.J., Sevink, J., 1992. The effects of fire and water repellency on infiltration and runoff under Mediterranean type forest. Catena, 19, 3-4, 345361. DOI: 10.1016/0341-8162(92)90008-Y.

Johansen, M.P., Hakonson, T.E., Breshears, D.D., 2001. Post-fire runoff and erosion from rainfall simulation: contrasting forests with shrublands and grasslands. Hydrol. Process., 15, 15, 29532965. DOI: 10.1002/hyp.384.

Kawamoto, K., Moldrup, P., Komatsu, T., de Jonge, L.W., Oda, M., 2007. Water repellency of aggregate size fractions of volcanic ash soil. Soil Sci. Soc. Am. J., 71, 6, 1658-1666. DOI: 10.2136/sssaj2006.0284.

Larsen, I.J., MacDonald, L.H., Brown, E., Rough, D., Welsh, M.J., Pietraszek, J.H., Libohova, Z., de Dios Benavides-Solorio, J., Schaffrath, K., 2009. Causes of post-fire runoff and erosion: Water repellency, cover, or soil sealing? Soil Sci. Soc. Am. J., 73, 1393-1407. DOI: 10.2136/sssaj2007.0432.

Lentile, L.B., Holden, Z.A., Smith, A.M.S., Falkowski, M.J., Hudak, A.T., Morgan, P., Lewis, S.A., Gessler, P.E., Benson, N.C., 2006. Remote sensing techniques to assess active fire characteristics and post-fire effects. Int. J. Wildland Fire, 15, 319-345. DOI: 10.1029/2006JG000230.

Lewis, S.A., Wu, J.Q., Robichaud, P.R., 2006. Assessing burn severity and comparing soil water repellency, Hayman Fire, Colorado. Hydrol. Process., 20, 1, 1-16. DOI: 10.1002/hyp.5880.

Lewis, S.A., Robichaud, P.R., Frazier, B.E., Wu, J.Q., Laes, D.Y.M., 2008. Using hyperspectral imagery to predict postwildfire soil water repellency. Geomorphology, 95, 192-205. DOI: 10.1016/j.geomorph.2007.06.002.

Madsen, M.D., Petersen, S.L., Fernelius, K.J., Roundy, B.A., Taylor, A.G., Hopkins, B.G., 2012. Influence of soil water repellency on seedling emergence and plant survival in a burned semiarid woodland. Arid Land Res. Manag., 26, 3, 236-249. DOI: 10.1080/15324982.2012.680655.

Martin, D.A., Moody, J.A., 2001. Comparison of soil infiltration rates in burned and unburned mountainous watersheds. Hydrol. Process., 15, 2893-2903. DOI: 10.1002/hyp.380.

Mataix-Solera, J., Guerrero, C., García-Orenes, F., BárcenasMoreno, G., Torres, M.P., 2009. Forest fire effects on soil microbiology. In: Cerdà, A., Robichaud, P.R. (Eds.): Fire Effects on Soils and Restoration Strategies. Science Publishers, Enfield, New Hampshire, USA, pp. 133-175.

Meyer, L.D., Harmon, W.C., 1979. Multiple-intensity rainfall simulator for erosion research on row sideslopes. T. Am. Soc. Civ. Eng., 22, 100-108.

Moody, J.A., Shakesby, R.A., Robichaud, P.R., Cannon, S.H., Martin, D.A., 2013. Current research issues related to postwildfire runoff and erosion processes. Earth-Sci. Rev., 122, 1037. DOI: 10.1016/j.earscirev.2013.03.004.

Natural Resources Conservation Service (NRCS), 2010. Keys to soil taxonomy $11^{\text {th }}$ ed. US Department of Agriculture, Natural Resources Conservation Service, Washington, DC. 
Natural Resources Conservation Service (NRCS), 2011. Official soil series descriptions. US Department of Agriculture, Natural Resources Conservation Service, Washington, DC. Available online [https://soilseries.sc.egov.usda.gov/osdname.asp] (accessed 15 June 2016)

National Water and Climate Center (NWCC), 2010. Atlanta Summit SNOTEL data. Available online [http://www.wcc.nrcs.usda.gov/snow/] (accessed 25 November 2016).

Neary, D.G., Ryan, K.D., DeBano, L.F., Landsberg, J.D., Brown, J.K., 2005. Chapter 1: Introduction. In: Neary, D.G., Ryan, K.D., DeBano, L.F. (Eds.): Wildland Fire in Ecosystems: Effects of Fire on Soil and Water. General Technical Report, RMRS-GTR-42, vol. 4. U.S. Department of Agriculture, Forest Service, Rocky Mountain Research Station, Ogden, UT, USA. pp. 1-17.

Pannkuk, C.D., Robichaud, P.R., 2003. Effectiveness of needle cast at reducing erosion after forest fires. Water Resour. Res., 39, 12, 1333-1344. DOI: 10.1029/2003WR002318.

Parsons, A., Robichaud, P.R., Lewis, S.A., Napper, C., Clark, J.T., 2010. Field guide for mapping post-fire soil burn severity. General Technical Report RMRS-GTR-243. US Department of Agriculture, Forest Service, Rocky Mountain Research Station, Ft. Collins, Colorado, USA, $49 \mathrm{p}$.

Pierson, F.B., Robichaud, P.R., Moffett, C.A., Spaeth, K.E., Hardegree, S.P., Clark, P.E., Williams, C.J., 2008. Fire effects on rangeland hydrology and erosion in a steep sagebrushdominated landscape. Hydrol. Process., 22, 16, 2916-2929. DOI: 10.1002/hyp.6904.

Prosser, I.P., Williams, L., 1998. The effect of wildfire on runoff and erosion in native Eucalypt forest. Hydrol. Process., 12, 2, 251-265. DOI: $10.1002 /($ SICI) $1099-$ 1085(199802)12:2<251:AID-HYP574>3.0.CO;2-4.

R Core Team, 2013. R: A Language and Environment for Statistical Computing. R Foundation for Statistical Computing, Vienna, Austria.

Robichaud, P.R., 2000. Fire effects on infiltration rates after prescribed fire in Northern Rocky Mountain forests. USA. J. Hydrol., 231-232, 220-229. DOI: 10.1016/S0022-1694(00)00196-7.

Robichaud, P.R.; Ashmun, L.E., 2013. Tools to aid post-wildfire assessment and erosion-mitigation treatment decisions. Int. J. Wildland Fire, 22, 1, 95-105. DOI: 10.1071/WF11162.

Robichaud, P.R., Elliott, W.J., Pierson, F.B., Hall, D.E., Moffett, D.E., Ashmun, L.E., 2007. Erosion Risk Management Tool (ERMiT) user manual (version 2006.01.18). General Technical Report RMRS-GTR-188. US Department of Agriculture, Forest Service, Rocky Mountain Research Station, Ft. Collins, Colorado, USA, 24 p.

Robichaud, P.R., Lewis, S.A., Ashmun, L.E., 2008. New procedure for sampling infiltration to assess post-fire soil water repellency. Research Note RMRS-RN-33. US Department of Agriculture, Forest Service, Rocky Mountain Research Station, Ft. Collins, Colorado, USA, 85 p.

Robichaud, P.R., Lewis, S.A., Wagenbrenner, J.W., Ashmun, L.E., Brown, R.E., 2013a. Post-fire mulching for runoff and erosion mitigation: Part I: Effectiveness at reducing hillslope erosion rates. Catena, 105, 75-92. DOI: 10.1016/j.catena.2012.11.015.

Robichaud, P.R., Wagenbrenner, J.W., Lewis, S.A., Ashmun, L.E., Brown, R.E., Wohlgemuth, P.M., 2013b. Post-fire mulching for runoff and erosion mitigation. Part II. Effectiveness in reducing runoff and sediment yields from small catchments. Catena, 105, 93-111. DOI: 10.1016/j.catena.2012.11.016.

Robichaud, P.R., Wagenbrenner, J.W., Pierson, F.B., Spaeth, K.E., Ashmun, L.E., Moffet, C.A., 2016. Infiltration and interrill erosion rates after a wildfire in western Montana, USA. Catena, 142, 77-88. DOI: 10.1016/j.catena.2016.01.027.
Ryan, K.C., 2002. Dynamic interactions between forest structure and fire behavior in boreal ecosystems. Silva Fenn., 36, 1, 13-39.

Ryan, K.C., Noste, N.V., 1985. Evaluating prescribed fires, General Technical Report INT-GTR-182. In: Lotan, J.E., Kilgore, B.M., Fischer, W.C., Mutch, R.W. (Eds.): Proc. Symposium and Workshop on Wilderness Fire. US Department of Agriculture, Forest Service, Intermountain Forest and Range Experimental Station, Ogden, Utah, USA, pp. 230-238.

Scott, D.F., Curran, M.P., Robichaud, P.R., Wagenbrenner, J.W., 2009. Soil erosion after forest fire. In: Cerdà, A., Robichaud, P.R. (Eds.): Fire Effects on Soils and Restoration Strategies. Science Publishers, Enfield, New Hampshire, USA, pp. 178-195.

Shakesby, R.A., Coelho, C.D.A., Ferreira, A.D., Terry, J.P., Walsh, R.P.D., 1993. Wildfire impacts on soil erosion and hydrology in wet Mediterranean forest, Portugal. Int. J. Wildland Fire, 3, 2, 95-110. DOI: 10.1071/WF9930095.

Shakesby, R.A., Doerr, S.H., Walsh, R.P.D., 2000.The erosional impact of soil hydrophobicity: current problems and future research directions. J. Hydrol., 231-232, 178-191. DOI: 10.1016/S0022-1694(00)00193-1.

Shakesby, R.A., Doerr, S.H., 2006. Wildfire as a hydrological and geomorphological agent. Earth-Sci. Rev., 74, 3-4, 269-307. DOI: $10.1016 / j$.earscirev.2005.10.006.

Steele, R., Pfister, R.D., Ryker, R.A., Kittams, J.A., 1981. Forest habitat types of central Idaho. General Technical Report INT114. US Department of Agriculture, Forest Service, Intermountain Forest and Range Experiment Station, Ogden, Utah.

Townsend, S.A., Douglas, M.M., 2000. The effect of three fire regimes on stream quality, water yield and export coefficients in a tropical savanna (northern Australia). J. Hydrol., 229, 3, 118137. DOI: 10.1016/S0022-1694(00)00165-7.

USDA Forest Service, 2003. Hot Creek Fire Burned Area Report. Available at https://forest.moscowfsl.wsu.edu/BAERTOOLS/baerdb/2500-8/2500-8_Hot\%20Creek\%20Fire_Boise.pdf (accessed 2 February 2017)

Vieira, D.C.S., Fernández, C., Vega, J.A., Keizer, J.J., 2015. Does soil burn severity affect the post-fire runoff and interrill erosion response? A review based on meta-analysis of field rainfall simulation data. J. Hydrol., 523, 452-464. DOI: 10.1016/j.jhydrol.2015.01.071.

Wagenbrenner, J.W., Robichaud, P.R., 2014. Post-fire bedload sediment delivery across spatial scales in the interior western United States. Earth Surf. Proc. Land., 39, 7, 865-876. DOI: 10.1002/esp.3488.

Wilcox, B.P., Wood, M.K., Tromble, J.M., 1988. Factors influencing infiltrability of semiarid mountain slopes. J. Range Manag., 41, 3, 197-206.

Williams, C.J., Pierson, F.B., Robichaud, P.R., Al-Hamdan, O.Z., Boll, J., Strand, E.K., 2016. Structural and functional connectivity as a driver of hillslope erosion following disturbance. Int. J. Wildland Fire, 25, 3, 306-321. DOI: 10.1071/WF14114.

Wine, M.L., Zou, C.B., Bradford, J.A., Gunter, S.A., 2012. Runoff and sediment responses to grazing native and introduced species on highly erodible Southern Great Plains soil. J. Hydrol., 450451, 336-341. DOI: 10.1016/j.jhydrol.2012.05.012.

Wine, M.L., Cadol, D., 2016. Hydrologic effects of large southwestern USA wildfires significantly increase regional water supply: Fact or fiction? Environ. Res. Lett., 11, 085006. DOI: 10.1088/1748-9326/11/8/085006.

Wondzell, S.M., King, J.G., 2003. Postfire erosional processes in the Pacific Northwest and Rocky Mountain regions. Forest Ecol. Manag., 178, 1-2, 75-87. DOI: 10.1016/S03781127(03)00054-9

Note: Colour version of Figures can be found in the web version of this article. 